\title{
Sulu Şartlarda Ekmeklik Buğdayda Başaklanma Döneminde Yaprak Solusyon Uygulamasının Tane Protein Kapsamı Üzerine Etkisi
}

\author{
Erdinç Savaşlı $^{1 *}$, Oğuz Önder ${ }^{1}$, Cemal Çekiç ${ }^{1}$, Hasan Müfit Kalaycı ${ }^{1}$, Ramis Dayığlu ${ }^{1}$, \\ Yaşar Karaduman', Fatma Gökmen², Nesim Dursun², Sait Gezgin²
}

${ }^{\text {I} G e c ̧ i t ~ K u s ̧ a g ̆ ı ~ T a r ı m s a l ~ A r a s ̧ t ı r m a ~ E n s t i t u ̈ s u ̈ ~} 26200$ Eskişehir, Türkiye

${ }^{2}$ Selçuk Üniversitesi, Ziraat Fakültesi, Toprak Bölümü, 42250 Konya, Türkiye

M A K A L E B İ L G İ S İ

\section{Araştırma Makalesi}

Geliş 19 Haziran 2017

Kabul 19 Aralik 2017

Anahtar Kelimeler:

Buğday

Protein

Yaprak solüsyonu

Yaprak azot(TN)

Gluten kalitesi

*Sorumlu Yazar:

E-mail: erdinc.savasli@ tarim.gov.tr

\section{Ö Z E T}

Bu çalışma, 2008-2010 yılları arasında Geçit Kuşağı Tarımsal Araştırma Enstitüsü ve Selçuk Üniversitesi iş birliğinde TÜBİTAK tarafından desteklenen araştırma sonuçlarına göre, sulu koşullarda Bezostayal ekmeklik buğday çeşidiyle, erken dönem azot uygulaması (ekim + kardeşlenme) $0,4,8$ ve $12 \mathrm{~kg} \mathrm{~N} \mathrm{da}^{-1}$, başaklanma zamanında ise yaprak solüsyonu (üre formunda) olarak 0,2 , 4 ve $6 \mathrm{~kg} \mathrm{~N} \mathrm{da}^{-1}$ seviyeleri karşılaştırılmıştır. Araștırmada, geleneksel azotlu gübre uygulama zamanında (ekim + kardeşlenme) uygulanan değişik azot seviyeleri başaklanma zamanında bayrak yaprak klorofil kapsamları (SPAD) ve bayrak yaprak toplam azot kapsamları (TN) açısından bir varyasyon yaratılmıştır. Çalışmanın sonuçlarına göre, başaklanma zamanında yapraktan uygulanan azotun tane protein kapsamında en az \%1 artış sağlayacağı NSPAD kritik eşik değerleri, Bezostaya1 için 0,95 olarak bulunmuştur. TN için bulunan kritik eşik değerleri ise, Bezostayal için \%4,31 olmuştur. Her bir $\mathrm{kg} \mathrm{da}^{-1} \mathrm{~N}$ miktarının tane protein kapsamında sağladığı artış, Bezostaya1 için, erken kullanımda \%0,18, geç kullanımda $\% 0,30$ olmuştur. Ayrıca, protein ve ilgili kalite unsurları üzerine hem erken, hem de geç azot kullanımı etkili olmakla birlikte, başaklanma döneminde yapraktan solüsyon olarak uygulamanın daha etkili olduğu belirlenmiştir. Bu özelliklerden, tane protein kapsamı ile SDS sedimentasyon $\left(\mathrm{r}=0,93^{* *}\right)$, Uzama kabiliyeti $\left(\mathrm{r}=0,96^{* *}\right)$, uzayabilirlik $\left(\mathrm{r}=0,96^{*}\right)$, hamur gelişme süresi $\left(\mathrm{r}=0,87^{* *}\right)$, tolerans değeri $\left(\mathrm{r}=0,56^{* *}\right)$ ve enerji değeri $\left(\mathrm{r}=0,89^{* *}\right)$ parametreler arasında istatistiki olarak önemli düzeyde korelasyon vermiştir.

Turkish Journal of Agriculture - Food Science and Technology, 6(1): 84-90, 2018

The Effects of Foliar Nitrogen Treatments at Heading Stage on Grain Protein Contents of Bread Wheat Cultivars in in Irrigated Condition

\section{A R T I C L E IN F O}

\section{Research Article}

Received 19 June 2017

Accepted 19 December 2017

Keywords:

Wheat

Protein

Foliar solution

Leaf Nitrogen(TN)

Gluten quality

*Corresponding Author:

E-mail: erdinc.savasli@ tarim.gov.tr

\section{A B S T R A C T}

This study, conducted by Transitional Zone Agricultural Research Institute in Eskisehir and Selçuk University and was a work packet of TUBİTAK funded project in 2008-2010 growing season. In this study, with using bread wheat cultivars (Bezostaya1) in irrigated condition, it was compared that $0,4,8$ and $12 \mathrm{~kg} \mathrm{~N} \mathrm{da}^{-1}$ in the early period nitrogen application, both planting and tillering stage and $0,2,4$ and $6 \mathrm{~kg} \mathrm{~N} \mathrm{da}^{-1}$ solution form using (Urea form) in heading stage. In this study, through with different nitrogen rates in traditional nitrogen application time a variation was created in terms of SPAD and TN at heading stage. According to results of the study, in irrigated conditions, it was found that application of nitrogen from leaves in heading stage can increase the protein content at least $1 \%$ and the critical threshold value of NSPAD was 0.95 for Bezostaya1, on the other hand the critical threshold value of TN critical was \% 4.31 for Bezostaya1 in same condition. The using of every $1 \mathrm{~kg} \mathrm{da}^{-1}$ of $\mathrm{N}$ was increased $0.18 \%$ in early application and $0.30 \%$ in late application for Bezostajal in grain protein content. Although both early and late applications was effective for protein content and related quality compounds, the application of leaf solution in heading stage was more dominant. From these properties, it has provided a significant high correlation in the level of protein content with SDS sedimentation $\left(r=0.93^{* *}\right)$, elongation ability $\left(r=0.96^{* *}\right)$, $\operatorname{extensibility}\left(r=0.96^{* *}\right)$, duration of dough development $(r=0.87 * *)$, tolerance value $(r=0.56 * *)$, and energy value $(r=0.89 * *)$. 


\section{Giriş}

Buğday tanesinin son kullanım kalitesini belirlemede protein kompozisyonu önemli olup, tanenin kalitatif kompozisyonunun genetik olarak belirlendiği, ancak kantitatif kompozisyonunun çevre koşullarından büyük ölçüde etkilendiği ve bu açıdan önemli düzeyde genotip $\times$ çevre $\times$ uygulama interaksiyonları görüldüğü rapor edilmiş̧ir (Zhu ve Khan, 2001).

Türkiye'de sulu kışlık buğday tarımında genel olarak azotlu gübre ekimle birlikte, kardeşlenmede ve nadiren geç dönem başaklanma döneminde azotlu gübreleme yapılmaktadır. Azotu çiftçinin ne zaman kullandığı değil, bitkinin ne zaman kullandığıdır. Bu konudaki literatür bildirilerinde farklı görüşler ileri sürülmüştür. Buna göre, tüm gelişme dönemince alınan azotun en az \%80'inin vejetatif gelişme döneminde alınarak tozlanma döneminde bitkide mevcut olduğunu (Austin ve ark., 1977; Heitholt ve ark., 1990), bunun muhtemelen tane doldurma döneminde kök aktivitesinin azalması ve azot alımının sınırlanmasıyla ilgili olduğunu (Frederick ve Bauer, 1999) ileri süren araştırıcılar olduğu gibi, buğdayın tozlanmadan sonra da azot alımına devam ettiğini (Oscarson ve ark., 1995; Van Sanford ve MacKown, 1987), koşullara göre, toplam azot alımının \%8 ile 35'ini tozlanmadan sonra gerçekleştirdiğini (Van Sanford ve MacKown, 1987), çünkü köklerin en son kuruyan organlar olup tane doldurma sirasinda aktivitelerini devam ettirdiklerini (Peoples ve Dalling, 1988) bildiren araştırıcılar da olmuştur. Ülkemizde yapılan bir çalışmada da, yapraktan üre uygulamasının buğday çeşitlerinde en yüksek tane protein oranlarını verdiği görülmüştür (Topal ve ark., 1997). Westcott ve ark. (1997) Montana'da sulu koşullarda yazlık buğdayla yaptığı çalışmada NSPAD değerinin 0,93-0,95 düzeyine düşmesi halinde ek gübrelemenin proteini arttırdığını, 0.89 NSPAD değerinde bu artışın \%1'i bulduğunu belirtmektedir. Yine Aynı araştırıcılar, aynı çalışmada, bayrak yaprak azot (TN) değerleriyle de ek azota karşılık arasında yüksek korelasyon bulmuşlar ve bu değerin \%4,2-4,3'ün altında olması halinde buğdayın tane proteini açısından ek azota karşı1lı vereceğini bildirmişlerdir. Kuru şartlarda yürütülen bir çalışmada, başaklanma zamanında yapraktan solusyon olarak uygulanan azotun tane protein kapsamında en az \%1 artış sağlayacağı NSPAD kritik eşik değerleri, Bezostaya1 için 0,96, Gerek79 için 0,94, bayrak yaprak azot (TN) için bulunan kritik eşik değerleri Bezostaya1 için \%4,22, Gerek 79 için 3,75 olarak kaydedilmiştir (Savasli ve ark., 2017).

$\mathrm{Bu}$ çalışmanın amacı, başaklanma zamanında uygulanan üre yaprak solusyon uygulamalarının tane protein kapsamı üzerine etkisi araştırılarak tane protein artışı için yaprak toplam azot ve NSPAD kritik eşik değerlerinin belirlenmesidir.

\section{Materyal ve Yöntem}

2008-2010 yılları arasında Eskișehir'deki Enstitüsü tarlalarında 3 yıl yürütülen bu çalışmada, 3 faktör olup, ana parseller azot uygulama zamanı (yarıs ekimle, yarısı kardeşlenmede) toprağa uygulanan $0,4,8$ ve $12 \mathrm{~kg} \mathrm{~N} \mathrm{da}^{-1}$ azot seviyeleri, alt parseller azotun uygulama şekli başaklanma zamanı i-) SS: Sulama suyuna karıştırarak uygulama (pülverize, ve damlacık çapı küçük olan) ii-) YS: Yaprak solusyon uygulama (atomize formunda verilen azotun uygulama) şekli, 3. faktör alt alt parseller başaklanma zamanında (geç azot) $0,2,4$ ve $6 \mathrm{~kg} \mathrm{~N}$ da-1 seviyesinde sulama suyuna karıştırarak ve yaprak solüsyon uygulama şeklinde Tesadüf Bloklarında Bölünen Bölünmüş Parseller deseninde ve 4 tekerrürlü olarak yürütülmüştür. Sadece başaklanma döneminde bayrak yaprak klorofil değerlerinde ve SPAD okumaları için varyasyon yaratma amacını güden erken (ekimle, kadeşlenme döneminde topraktan) dönemde topraktan farklı azot gübre dozları uygulanmıştır. Son dönemde (başaklanma dönemi) ise en uygun gübre üre olduğundan, hem sulama suyuna karıştırma hem de yaprak solüsyon uygulamalarında üre formu kullanılmıştır. Yaprak solüsyonlarının uygulanmasında azotlu gübre atomizör ile $\% 4$ 'lük üre solüsyonları halinde $2 \mathrm{~kg} \mathrm{~N} \mathrm{da}^{-1}$ için 40 litre dekar olmak üzere 4 ve $6 \mathrm{~kg} \mathrm{~N} \mathrm{da}^{-1}$ için 80 litre ve 120 litre dekar solusyon 1 hafta arayla 2 defada verilirken, sulama suyuna karıştırarak pülverizatör ile yaprak yanma tehlikesi olmadığından sulama öncesinde $(80,160,240$ litre dekar solusyon) bir defada verilmiştir.

$\mathrm{Bu}$ çalışmada, Bezostayal ekmeklik buğday çeşidi 450 tane metrekare ${ }^{-1}$ tohum sıklığ kullanılmıştır. Deneme parselleri ekilişte $1,3 \times 7=9,1$ metrekare, hasatta ise $1,3 \times$ $5=6,5$ metrekare olarak alınmıştır. Yapraktan solusyon uygulamaları başaklanma zamanında yapılan son sulamayla yapılmıştır. Sulama öncesinde, toprağın $0-90$ $\mathrm{cm}$ profil derinliğini tarla kapasitesine getirmek için gerekli su miktarı belirlendikten sonra, parsel başına gereken su sirt atomizörleriyle verilerek çiftçinin yağmurlama suyuna karıştırma uygulamasına yakın bir uygulama gerçekleştirilmiştir. Denemede de fosfor Triple Süper Fosfat formunda ve toprak analiz sonuçlarına göre uygulandıktan sonra, ekimdeki azot uygulamalarında amonyum sülfat, ilkbaharda ise çiftçi uygulamalarına paralellik olması bakımından amonyum nitrat kullanılmıştır.

Bugün yaygın olarak kullanılan Minolta SPAD-502 klorofilmetre (Markwell ve ark., 1995), yaprakların klorofil yoğunluğunu SPAD birimi olarak vermekte ve genellikle değerlendirmeler bu birim üzerinden yapılmaktadır. Başaklanma zamanında SPAD okumaları, her bir parselden rastgele seçilen 10 bitkinin ana saplarındaki bayrak yapraklarında ve 3 ayrı kesimde yapılan okumaların ortalaması alınarak yapılmışıtır. Parsellerden bu şekilde elde olunan SPAD değerleri, aynı genotipin en yüksek dozda gübrelenen parsellerinden elde olunan SPAD değerlerine bölünerek relatif olarak ifade edilmiştir ki buna normalizasyon işlemi adı verilmektedir. Buna göre:

$$
\text { NSPAD }=\text { SPAD }(\text { parsel) } / \text { SPAD (maximum) }
$$

\section{NSPAD: Normalize edilmiş SPAD}

Ana sap bayrak yaprakları seçilerek her parselden alınan 30 yaprakta, Selçuk Üniversitesi, Ziraat Fakültesi, Toprak Bilimi ve Bitki Besleme Bölümü tarafından Dumas Metoduna göre (AACC, 2000) toplam azot tayinleri yapılmıştır. 
Perten 3100 değirmeni (Retsch,Haan,Germany) ile 0,5 $\mathrm{mm}$ partikül iriliğinde kırmaya (tam tane ununa) Chopin CD1 değirmeni un öğütmede kullanılmıştır.

Alveograf özellikleri modifiye AACC 54-30'a göre değerlendirilmiştir (Anonymous, 2000). Öncelikli olarak su absorpsiyon değerleri AACC 54-50'ye göre konsistograf ile belirlenmiş alveograf testinde bu su absorpsiyon değerleri kullanılmıştır (Anonymous, 2000). CIMMYT-SDS (C-SDS) sedimentasyon analizi Pena vd. (1990) belirtilen metoda göre $25 \mathrm{ml}$ test tüplerinde yapılmıştır.

Araştırmanın Enstitümüzde yürütülmüş olduğu yıllara ait yağış miktarları Çizelge 1'de verilmiştir. Toprak analizleri örnekleri kurutulmadan araziden alındığı nemde Bremner (1965) tarafından önerilen 2 farklı yöntemle $\mathrm{NO}_{3}$ ve $\mathrm{NH}_{4}+\mathrm{NO}_{3}$ azotu analizleri yapılmıştır. $\mathrm{Bu}$ örneklerde elde olunan analiz sonuçlarından, deneme kurulan alanlara ait veriler Çizelge 2'de verilmiştir.

Çizelge 2'de görüldüğü gibi deneme alanlarının toprak nitrat azotu orta düzeydedir. Deneme yerleri seçilmeden önce örnek alınan tarlalardan bu özellikleriyle seçilmişlerdir. Deneme yeri topraklarının killi bünyeye ve orta (\%1-2) düzeyde organik madde içeriğine sahip olduğu da görülmektedir. Ayrıca deneme yeri toprakları orta (\%5-15) ve fazla (\%15-25) kireçli, hafif alkalin reaksiyonlu, düşük tuzlu veya tuzsuzdur.

\section{Verilerin analizi}

Verilerin istatistiksel analizi JMP istatistik programı ( JMP, 2016: JMP Users Guide. Version 13.0.0, SAS Institute Inc., Cary, NC,USA. ) aracılığıyla yapılmıştır. Varyans analizi aracılığıyla uygulama etkilerinin önemlilik derecesi test edildikten sonra, ortalamaların karşılaştırılmasında Student's t yöntemi kullanılmıştır. Varyans analizini takiben regresyon ve korelasyon analizlerine başvurulmuştur. $\mathrm{Bu}$ denemeye özel olarak, tane proteinine erken ve geç uygulamaların göreli etkilerini karşılaştırmak üzere Stepwise yöntemiyle çoklu regresyon analizine başvurulmuştur.

Çizelge 1 Enstitüde ölçülen yağış miktarları (2007-2010).

\begin{tabular}{l|rrrrrrrrrrrrr}
\hline YILLAR & \multicolumn{1}{|c}{ EYL } & EKM & KAS & \multicolumn{1}{c}{ ARA } & OCK & ŞUB & MAR & NIS & MAY & HAZ & TEM & AĞS & Y1ll1k Top.(mm) \\
\hline Uzun y11 & 14,7 & 25,2 & 30,6 & 45,6 & 38,4 & 32,6 & 33,3 & 35,0 & 42,1 & 29,3 & 13,8 & 6,5 & 347 \\
$2007-08$ & 0,0 & 19,2 & 92,4 & 49,9 & 15,7 & 1,0 & 42,4 & 38,5 & 11,7 & 9,3 & 0,0 & 5,5 & 286 \\
$2008-09$ & 30,7 & 6,4 & 49,6 & 34,5 & 66,3 & 82,0 & 40,9 & 28,0 & 15,4 & 10,2 & 19,4 & 2,0 & 385 \\
$2009-10$ & 7,1 & 9,0 & 29,5 & 65,1 & 36,0 & 42,8 & 32,6 & 23,9 & 20,7 & 79,0 & 7,4 & 0,9 & 354 \\
\hline
\end{tabular}

Çizelge 2 Deneme yerlerinden alınan toprakların kimyasal özellikleri $(0-30 \mathrm{~cm})$.

\begin{tabular}{|c|c|c|c|c|}
\hline Toprak özellikleri & Birimi & $\begin{array}{c}2007 \\
\text { MÜES }\end{array}$ & $\begin{array}{c}2008 \\
\text { MÜES }\end{array}$ & $\begin{array}{c}2009 \\
\text { MÜES }\end{array}$ \\
\hline *Tekstür Sınıf & & $\mathrm{C}$ & $\mathrm{C}$ & $\mathrm{C}$ \\
\hline pH (1:2.5.Toprak:Su) & & 7,83 & 7,52 & 7,54 \\
\hline EC (Tuz) (1:5,Toprak:Su) & $(\mu \mathrm{S} / \mathrm{cm})$ & 156,1 & 140 & 230 \\
\hline $\mathrm{CaCO}_{3}$ (Kireç) & $(\%)$ & 10,9 & 9,6 & 8,0 \\
\hline Organik Madde & $(\%)$ & 1,13 & 1,1 & 1,77 \\
\hline Fosfor $(\mathrm{P})$ & $\mathrm{mg} \mathrm{kg}^{-1}$ & 33,3 & 32,1 & 27,8 \\
\hline Potasyum $(\mathrm{K})$ & $\mathrm{mg} \mathrm{kg}{ }^{-1}$ & 671,8 & 666,7 & 493 \\
\hline Fenoldisülfonik Asit Metodu $\left(\mathrm{NO}_{3}\right)$ & $m g \mathrm{~kg}^{-1}$ & 2,42 & 3,30 & 0,46 \\
\hline $\mathrm{KCl}$ ile Ekstraksiyon Metodu $\left(\mathrm{NH}_{4}{ }^{+}, \mathrm{NO}_{3}\right)$ & $\mathrm{mg} \mathrm{kg}^{-1}$ & 10,52 & 15,90 & 7,5 \\
\hline
\end{tabular}

$* \mathrm{C}=\mathrm{Killi}$ (Clay).

\section{Bulgular ve Tartışma}

Çizelge 3' den de görüldüğü gibi, tane verimi üzerine erken dönem azot uygulamaları önemli olmuş, genel ortalama olarak erken azot kullanımına verim açısından karşılığın $426 \mathrm{~kg} \mathrm{da}^{-1}$ ile $4 \mathrm{~kg} \mathrm{~N} \mathrm{da}{ }^{-1}$ seviyesinde olduğu daha sonraki artan 8 ve $12 \mathrm{~kg} \mathrm{~N} \mathrm{da}^{-1}$ azot dozlarında ise verimde artış olmadığ $1\left(425-427 \mathrm{~kg} \mathrm{da}^{-1}\right)$ istatistiki olarak aynı grupta yer aldığı tespit edilmiştir. Geç dönem yaprak azot uygulamalarında yapraktan azot uygulanmayan kontrol parselinde ortalama verim $407 \mathrm{~kg}$ $\mathrm{da}^{-1}$ olurken, yapraktan $6 \mathrm{~kg} \mathrm{~N} \mathrm{da}^{-1}$ seviyesinde ortalama verim $412 \mathrm{~kg} \mathrm{da}^{-1}$ gerçekleşmiş ve yapraktan azot uygulamalarının tek başına verim üzerine etkili olmadığ anlaşılmıştır. Yaprak solüsyonlarının pülverizatör (sulama) ve atomizör kullanılarak karşılaştırıldığ uygulama yöntemlerinde pülverizatörde ortalama verim $409 \mathrm{~kg} \mathrm{da}^{-1}$, atomizörde ise $411 \mathrm{~kg} \mathrm{da}^{-1}$ gerçekleşmiş olup uygulama yönteminin verim üzerine etkili olmadığ anlaşılmıştır (Çizelge 3).
$\mathrm{Bu}$ çalışmanın asıl amacı, başaklanma zamanında kullanılan azotun tane veriminden çok, bütün dünyada da üzerinde yoğun çalışmalar yapılan, tane protein kapsamları üzerine etkisini belirlemektir.

\section{Tane Protein Kapsamlar}

Protein miktarı genotipik faktörler ve toprak azotu ve iklim koşulları gibi çevresel faktörlere bağlı olup (Bushuk,1988) kompozisyonu ile birlikte hamur özellikleri ve ürünün pişirme, tekstür ve görünüm özelliklerini belirleyen temel bir faktördür (Carson ve Edwards, 2009)

Çizelge 4' deki veriler erken (topraktan) ve geç dönemde (yapraktan) uygulanan azotun da tane protein oranındaki artışta istatistiksel olarak önemli düzeyde etkili olduğunu görülmektedir. Pülverizatör ve atomizörden oluşan uygulama yöntemleri arasında tane protein kapsamlarını yönünden bir farkılık görülmemiştir 
(Çizelge 4). Çizelge 4' te görüleceği üzere hiç azotlu gübre kullanılmayan kontrol parsellerinde bile $343 \mathrm{~kg} \mathrm{da}^{-1}$ verim ile tane protein kapsam1 $\% 12,9$ olurken, topraktan 8 $\mathrm{kg} \mathrm{N} \mathrm{da}{ }^{-1}$ yapraktan $6 \mathrm{~kg} \mathrm{~N} \mathrm{da}^{-1}$ uygulama seviyesinde tane verimi $424 \mathrm{~kg} \mathrm{da}^{-1}$, tane protein kapsamı ise $\% 15,5$ 'e yükselmiştir. Çizelge 2'de de görüldüğü gibi toprak analiz sonuçlarına göre topraktaki inorganik azot kapsamının yüksek olduğu görülmektedir.

Hiç azotlu gübre verilmeyen kontrol parsellerinde 3 denemenin ortalamas1 olarak, \%12,9 tane protein kapsamına sahipken, en yüksek protein kapsamı elde olunan uygulamalar itibariyle, Bezostayal'in tane protein kapsamı \%2,6'lik artışla \%15,5'e yükselmiştir. Her iki maksimum değer de en yüksek azotlu gübre kombinasyonunun kullanıldığ $18 \mathrm{~kg} \mathrm{~N} \mathrm{da}^{-1}$ erken $+6 \mathrm{~kg} \mathrm{~N}$ $\mathrm{da}^{-1}$ geç azot uygulamasıyla elde olunmuştur. Erken ve geç kullanımların tane proteinine katkılarını karşılaştırdığımızda, her bir birim azotun, proteinde sağladığı artış geç kullanımda daha fazla olmuştur. Bu durumda, bu iki kullanım zamanlarının tane protein kapsamına göreli katkılarını hesaplayabilmek için, STEPWISE yöntemiyle çoklu regresyon analizine başvurulmuş ve aşağıda verilen denklem elde olunmuştur

$$
\begin{aligned}
& \text { BEZOSTAYA1 } \\
& \text { TP }=12,9+0,18 \times \text { E.A. }+0,32 \times \text { G.A. }-0,016 \times(\text { E.A. } \times \text { G.A. }) \\
& \left(\mathrm{R}^{2}=0,913^{* *}, \mathrm{n}=16\right) \\
& \text { TP }=\text { Tane proteini }(\%) \\
& \text { E.A }=\text { Erken azot }\left(\mathrm{kg} \mathrm{N} \mathrm{da}^{-1}\right) \\
& \text { G.A }=\text { Geç azot }\left(\mathrm{kg} \mathrm{N} \mathrm{da}^{-1}\right)
\end{aligned}
$$

Denklemlerde eşitlik 2'den de görüldüğü gibi, her bir $\mathrm{kg} \mathrm{da}^{-1} \mathrm{~N}$ miktarının tane protein kapsamında sağladığ artış, Bezostaya1 için, erken kullanımda $\% 0,18$, geç kullanımda \%0,32 olmuştur. Bu beklenen bir sonuç olarak değerlendirilmiştir, çünkü geç dönem azot uygulamalarının tane protein kapsamı üzerine daha etkili olduğuna ilişkin çok sayıda araştırma bulgusu vardır (Finney ve ark., 1957; Strong, 1982; Wuest ve Cassman, 1992). Eşitlik 2' incelendiğinde, erken ve geç kullanımlar arasındaki negatif interaksiyonun da denklemlere girdiği görülmektedir. Bunun anlamı, erken dönemde kullanılan azot miktarı arttıkça, geç dönemde uygulanan azotun tane protein kapsamına katkısı azalmaktadır. Buradan da erken kullanım belli bir düzeyi geçtiğinde, geç kullanımın önemli bir katkı sağlamayabileceği sonucu çıkmaktadır.
$\mathrm{Bu}$ denemenin sonuçları ilişkinin varlığını ve düzeyini göstermekle birlikte, yine de verilen denklemler bu denemenin yürütüldüğü koşulları temsil etmektedir.

Geç dönemde yapılan azot uygulamalarının etkili olup olmayacağı, uygulamanın yapıldığ beslenme durumuna bağlı olduğundan, bu konuda değişik yöntemler geliştirilmiş olup, bunlardan en yaygın kullanılanlar, başaklanma zamanında bayrak yaprak toplam azotu (TN) kapsamını belirlemek (Doerge ve ark., 1991; Westcott ve ark., 1997); ya da yaprak klorofil yoğunluklarının yaprak azot kapsamıyla çok yakın ilişki verdiği belirlendiğinden (Peng ve ark., 1996), yaprak klorofil yoğunluklarını ölçen klorofilmetre kullanımı (Markwell ve ark., 1995; Westcott ve ark., 1997) olmaktadir.

$\mathrm{Bu}$ yaklaşımlarda, geç uygulamaya karşılık almanın beklenebileceği en yüksek TN veya NSPAD değerleri kritik eşik olarak tespit edilmektedir. ABD' de Montana' da yapılan bir çalışmada da 0,93-0,95 NSPAD değerleri kritik eşik olarak tespit edilmiş olmakla birlikte, o çalışmada \%1 protein artışının ancak NSPAD değeri 0,89'a düştüğünde mümkün olduğu görülmüştür (Westcott ve ark., 1997). NSPAD için bulunan kritik eşik değerleri normalizasyon işlemi dolayısıyla çoğu çeşit için kullanılabilir olduğu halde, TN için kritik eşik değerlerinin genotipler arası farklılık dolayısıyla her genotip için ayrı ayrı bulunması veya bu değerin de NSPAD gibi maksimumun yüzdesi olarak ifade edilmek suretiyle normalizasyon işlemine tabi tutulması gerekmektedir.

Montana'da yapılan iki çalışmadan ilkinde TN için kritik eşik \%4,2-4,3 olarak bulunurken (Westcott ve ark., 1997), ikincisinde de yine \%4,2 bulunmuştur (Lorbeer ve ark., 2000). Sulu koşullarda yaprak solüsyonu denemesinde erken ve geç dönemde kullanılan azotlu gübre dozlarının başaklanma zamanındaki SPAD, NSPAD, TN değerleri ve protein artışı üzerine etkisi olduğu Çizelge 5'de görülmektedir.

Sulu koşullardaki ekonomik değerlendirmelerde, 3 yılın ortalama NSPAD değerleri çok dar sınırlar içinde değiştiğinden ve bu değerlerin dışındaki NSPAD değerleri için ekstrapolasyon yöntemiyle doz belirlemek uygun

\begin{tabular}{|c|c|c|c|c|c|c|c|c|c|c|c|}
\hline \multirow{3}{*}{$\begin{array}{c}\text { Erken Azot } \\
\left(\mathrm{kg} \mathrm{N} \mathrm{da}^{-1}\right)\end{array}$} & \multicolumn{11}{|c|}{ Azot Geç $\left(\mathrm{kg} \mathrm{N} \mathrm{da}^{-1}\right)$} \\
\hline & \multicolumn{2}{|c|}{0} & \multicolumn{2}{|c|}{2} & \multicolumn{2}{|c|}{4} & \multicolumn{2}{|c|}{6} & \multicolumn{2}{|c|}{ Ortalama } & \multirow{2}{*}{ Ortalama } \\
\hline & $\mathrm{SS}$ & YS & SS & YS & SS & YS & SS & YS & SS & YS & \\
\hline 0 & 315 & 372 & 370 & 373 & 423 & 360 & 334 & 357 & 361 & 365 & $363^{\mathrm{b}}$ \\
\hline 4 & 422 & 452 & 397 & 399 & 438 & 425 & 425 & 447 & 420 & 431 & $426^{\mathrm{a}}$ \\
\hline 8 & 418 & 430 & 421 & 392 & 420 & 470 & 424 & 424 & 421 & 429 & $425^{\mathrm{a}}$ \\
\hline 12 & 420 & 427 & 434 & 414 & 424 & 409 & 452 & 437 & 432 & 422 & $427^{\mathrm{a}}$ \\
\hline Ortalama & 393 & 420 & 405 & 395 & 426 & 416 & 409 & 416 & 409 & 412 & 410 \\
\hline Ortalama & \multicolumn{2}{|c|}{407} & \multicolumn{2}{|c|}{400} & \multicolumn{2}{|c|}{421} & \multicolumn{2}{|c|}{412} & \multicolumn{2}{|c|}{410} & \\
\hline
\end{tabular}
bulunmadığ 1 için, 0,93 NSPAD için 4,3 $\mathrm{kg} \mathrm{N} \mathrm{da}^{-1}, 0,94$ NSPAD için 2,8 $\mathrm{kg} \mathrm{N} \mathrm{da}^{-1}$ ve $0,95 \mathrm{NSPAD}$ için $2,0 \mathrm{~kg} \mathrm{~N}$ $\mathrm{da}^{-1}$ kritik eşik olarak belirlenen 0,95 NSPAD değerleri arasında hesaplanan ekonomik azot dozları verilmiştir.

Çizelge 3 Bezostaya1 çeşidiyle yürütülen erken dönemde ve yapraktan uygulanan azotun tane verimi üzerine etkisi (3 yıl)

DK (\%):9,2; AÖF (0,05) Erken=46,4*; AÖF $(0,05)$ Geç=Ö.D; AÖF $(0,05)$ Yöntem= Ö.D; AÖF $(0,05)$ Erken*Geç= Ö.D; SS: Sulama suyuna
karıștırarak uygulama (pülverize, ve damlacık çapı küçük olan); YS: Yaprak solusyon uygulaması (atomize formunda verilen azotun uygulama);
karıştırarak uygulama (pülverize, ve damlacık çapı küçük olan); YS: Yaprak solusyon uygulaması (atomize formunda verilen azotun uygulama); **: \%1 düzeyinde önemli *: \%5 düzeyinde önemli Ö.D.: Önemli değil 
Çizelge 4 Bezostaya1 çeşidiyle yürütülen erken ve geç dönemde yapraktan uygulanan azotun tane protein kapsamı üzerine etkisi ( 3 y1l).

\begin{tabular}{|c|c|c|c|c|c|c|c|c|c|c|c|c|}
\hline \multirow{3}{*}{$\begin{array}{l}\text { Erken Azot } \\
\left(\mathrm{kg} \mathrm{N} \mathrm{da}^{-1}\right)\end{array}$} & \multicolumn{12}{|c|}{ Azot Geç $\left(\mathrm{kg} \mathrm{N} \mathrm{da}^{-1}\right)$} \\
\hline & \multicolumn{3}{|c|}{0} & \multicolumn{2}{|c|}{2} & \multicolumn{2}{|c|}{4} & \multicolumn{2}{|c|}{6} & \multicolumn{2}{|c|}{ Ortalama } & \multirow{2}{*}{ Ortalama } \\
\hline & SS & $\mathrm{Y}$ & & SS & YS & SS & YS & SS & YS & SS & YS & \\
\hline 0 & 12,8 & 13 & & 13,2 & 13,7 & 13,6 & 13,9 & 14,1 & 14,4 & 13,4 & 13,8 & $13,6^{\mathrm{c}}$ \\
\hline 4 & 13,2 & 13 & & 14,9 & 14,1 & 15,1 & 14,7 & 15,6 & 15,1 & 14,7 & 14,4 & $14,5^{\mathrm{b}}$ \\
\hline 8 & 15,1 & 13 & & 15,5 & 14,3 & 15,7 & 14,6 & 15,8 & 15,2 & 15,5 & 14,5 & $15,0^{\mathrm{a}}$ \\
\hline 12 & 15,1 & 14 & & 15,4 & 15,0 & 15,5 & 15,0 & 15,9 & 14,8 & 15,5 & 14,9 & $15,2^{\mathrm{a}}$ \\
\hline Ortalama & 14,0 & 13 & & 14,7 & 14,3 & 15,0 & 14,6 & 15,3 & 14,9 & 14,8 & 14,4 & 14,6 \\
\hline Ortalama & & & & & $5^{\mathrm{c}}$ & & & & & & & \\
\hline \multicolumn{13}{|c|}{ 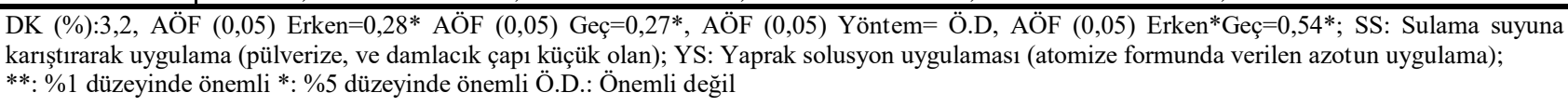 } \\
\hline \multicolumn{13}{|c|}{$\begin{array}{l}\text { Çizelge } 5 \text { Sulu koşullarda yaprak solüsyonu denemesinde erken ve geç dönemde kullanılan azotlu gübre dozlarının } \\
\text { başaklanma zamanındaki SPAD, NSPAD, TN değerleri ve protein artıșı üzerine etkisi (3 Yıl). }\end{array}$} \\
\hline \multicolumn{3}{|c|}{ Azot (E.A) $\left(\mathrm{kgN} \mathrm{da}^{-1}\right)$} & \multicolumn{2}{|c|}{ SPAD } & $\mathrm{TN}(\%)$ & \multicolumn{2}{|c|}{ NSPAD } & \multicolumn{4}{|c|}{ BAYRAK TN(\%) YAPRAK } & Protein Artış1 (\%) \\
\hline \multicolumn{3}{|c|}{0} & \multicolumn{2}{|c|}{$40,9^{\mathrm{d}}$} & $3,94^{\mathrm{d}}$ & \multicolumn{2}{|c|}{0,93} & \multicolumn{4}{|c|}{3,94} & 1,3 \\
\hline \multicolumn{3}{|l|}{4} & \multicolumn{2}{|c|}{$43,0^{c}$} & $4,09^{\mathrm{c}}$ & \multicolumn{2}{|c|}{0,93} & \multicolumn{4}{|c|}{4,09} & 2,0 \\
\hline \multicolumn{3}{|l|}{8} & \multicolumn{2}{|c|}{$44,7^{\mathrm{b}}$} & $4,26^{\mathrm{b}}$ & \multicolumn{2}{|c|}{0,95} & \multicolumn{4}{|c|}{4,26} & 1,0 \\
\hline \multicolumn{3}{|l|}{12} & & $9^{\mathrm{a}}$ & $4,54^{\mathrm{a}}$ & \multirow{4}{*}{\multicolumn{2}{|c|}{0,99}} & \multirow{2}{*}{\multicolumn{4}{|c|}{4,54}} & 0,4 \\
\hline \multicolumn{3}{|l|}{ Ortalama } & &, 7 & 4,22 & & & & & & & \\
\hline \multicolumn{3}{|l|}{ DK $(\%)$} & & 5 & 4,1 & & & & & & & \\
\hline \multicolumn{3}{|l|}{ AÖF $(0,05)$} & & $1 *$ & $0,11 *$ & & & & & & & \\
\hline
\end{tabular}

**: \%1 düzeyinde önemli *: \%5 düzeyinde önemli Ö.D.: Önemli değil (E.A: Erken Azot uygulama)

Çizelge 6 Sulu koşullarda yaprak solüsyonu denemesinde erken ve geç dönemlerde kullanılan azotlu gübre dozlarının kalite parametreleri üzerine etkisi (3 yıl ortalaması)

\begin{tabular}{|c|c|c|c|c|c|c|}
\hline $\begin{array}{l}\text { Azot Dozu } \\
\left(\mathrm{Kg} \mathrm{N} \mathrm{da}^{-1}\right)\end{array}$ & $\begin{array}{l}\text { SDS } \\
(\mathrm{ml})\end{array}$ & $\begin{array}{l}\text { TPR MAX } \\
\text { Değeri(s) }\end{array}$ & $\begin{array}{c}\text { Su kal. } \\
\text { Değeri }(\%)\end{array}$ & $\begin{array}{c}\text { Uzama kab. } \\
\text { Değ.i A (mm) }\end{array}$ & $\begin{array}{l}\text { Uzayabilirlik } \\
\text { Değeri (EX) }\end{array}$ & $\begin{array}{c}\text { Enerji } \\
\text { Değeri (J) }\end{array}$ \\
\hline \multicolumn{7}{|c|}{ Azot (ERKEN) $\left(\mathrm{kg} \mathrm{N} \mathrm{da}^{-1}\right)$} \\
\hline 0 & $9,5^{\mathrm{b}}$ & $148,3^{b}$ & 55,6 & $114,0^{\mathrm{b}}$ & $23,4^{\mathrm{b}}$ & 130,1 \\
\hline 4 & $9,8^{\mathrm{b}}$ & $160,7^{\mathrm{ab}}$ & 56,2 & $124,2^{\mathrm{ab}}$ & $24,6^{\mathrm{a}}$ & 137,4 \\
\hline 8 & $10,4^{\mathrm{a}}$ & $169,2^{\mathrm{a}}$ & 55,7 & $132,4^{\mathrm{a}}$ & $25,3^{\mathrm{a}}$ & 141,8 \\
\hline 12 & $10,5^{\mathrm{a}}$ & $175,7^{\mathrm{a}}$ & 55,8 & $133,2^{\mathrm{a}}$ & $25,5^{\mathrm{a}}$ & 147,1 \\
\hline Ortalama & 10,1 & 163,9 & 55,8 & 126,3 & 24,7 & 139,3 \\
\hline DK $(\%)$ & 7,2 & 8,4 & 11 & 8,1 & 4,6 & 6,4 \\
\hline AÖF $(0,05)$ & $0,41 *$ & $14,1^{*}$ & Ö.D & $14,9 *$ & $1,07^{*}$ & Ö.D \\
\hline \multicolumn{7}{|c|}{ Azot (GEÇ) $\left(\mathrm{kgN} \mathrm{da}^{-1}\right)$} \\
\hline 0 & $9,2^{\mathrm{c}}$ & $145,1^{\mathrm{b}}$ & 55,2 & $108,8^{\mathrm{d}}$ & $22,8^{\mathrm{d}}$ & $131,0^{\mathrm{c}}$ \\
\hline 2 & $9,8^{\mathrm{b}}$ & $151,7^{\mathrm{b}}$ & 56 & $118,6^{c}$ & $24,0^{\mathrm{c}}$ & $137,8^{\mathrm{bc}}$ \\
\hline 4 & $10,6^{\mathrm{a}}$ & $176,8^{\mathrm{a}}$ & 56,1 & $133,6^{\mathrm{b}}$ & $25,6^{\mathrm{b}}$ & $141,9^{\mathrm{ab}}$ \\
\hline 6 & $10,8^{\mathrm{a}}$ & $182,7^{\mathrm{a}}$ & 56 & $144,4^{\mathrm{a}}$ & $26,6^{\mathrm{a}}$ & $146,8^{\mathrm{a}}$ \\
\hline Ortalama & 10,1 & 163,9 & 55,8 & 126,3 & 24,7 & 139,3 \\
\hline DK $(\%)$ & 7,2 & 8,4 & 11 & 8,1 & 4,6 & 6,4 \\
\hline AÖF $(0,05)$ & $0,44 *$ & $13,9 *$ & Ö.D & $7,7 *$ & $0,97^{*}$ & $7,5^{*}$ \\
\hline
\end{tabular}

Çizelge 7 Değişik kalite parametreleriyle, tane protein kapsamı arasındaki korelasyon katsayıları.

\begin{tabular}{l|c}
\hline \multicolumn{1}{c}{ Parametre } & Proteinle Korelasyon Katsay1sı (N =16) \\
\hline SDS Sedimentasyon (ml) & $0,93^{* *}$ \\
Uzama Kabiliyeti (A) (mm) & $0,96^{* *}$ \\
Uzayabilirlik (EX) & $0,96^{* *}$ \\
Enerji Değeri (J) & $0,89^{* *}$ \\
Hamur Gelişme Süresi (s) & $0,87^{* *}$ \\
Tolerans Değeri & $0,59^{*}$ \\
Su Kaldırma (\%) & Ö.D \\
\hline **: \%1 düzeyinde önemli *: \%5 düzeyinde önemli Ö.D: Önemli değil
\end{tabular}



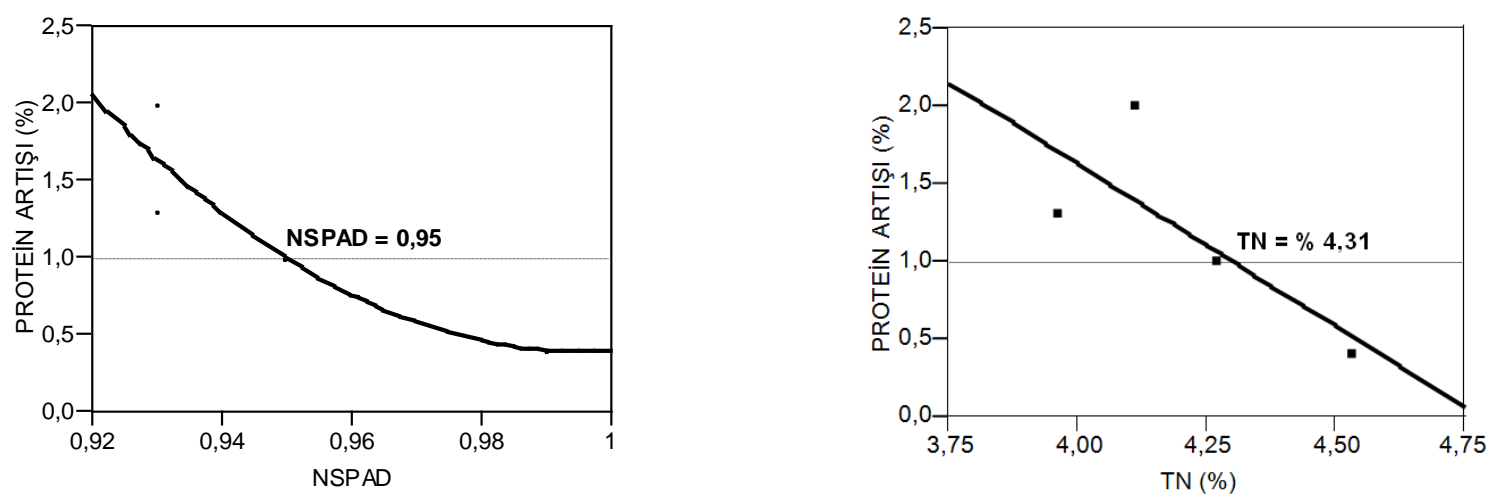

Şekil 1 Suluda yaprak solüsyonu denemesinde, Bezostaya çeşidi için belirlenen NSPAD ve TN kritik eşik değerleri

Sonuç olarak; sulu koşullarda kritik eşik olarak belirlenen NSPAD değerlerinin üzerinde okuma yapıldığında geç dönem azot uygulaması \%1 ve üzerinde protein artışı sağlamadığ 1 için ekonomik olmamakta, bu kritik eşik değerlerinin altındaki okumalarda ise NSPAD değeri düştükçe ekonomik azot dozu artmaktadır. Bu hususun dikkate alınması erken dönemde fazla azot kullanılan ve/veya pancar, patates gibi toprakta fazla bakiye azot bırakan münavebe bitkilerinden sonra ekilen buğdayda, bu dönemde gereksiz azot kullanımını engelleyerek, girdi ekonomisine yararlı olacaktır. Şekil 1' de görüldüğü gibi, Bezostaya1 çeşidiyle yürütülen suluda yaprak solüsyonu denemesinde NSPAD için 0,95 , bayrak yaprak toplam azot kapsamı içinse \%4,31 kritik eşik değerleri belirlenmiş̧ir.

Gluten (özellikle glutenin proteinlerinin) kuvvetinin belirlenmesinde sedimentasyon testleri (SDS ve Zeleny) birçok araştırma kuruluşu tarafından kullanılmaktadır ve daha çok kalıtımın etkisi altında olan bir kriterlerdir (Zeleny,1971; Atl1,1987; Karaduman 2015).

Çizelge 6'dan da görüldüğü gibi, erken ve geç dönem azot uygulamasının sedimentasyon değerlerini, TPR Max, (hamurun gelişme süresi) değeri, uzama kabiliyeti değerini ve uzayabilirlik değerleri üzerine istatistiki önemli düzeyde etkisi olduğu tespit edilmiş̧ir. Bezostaya çeșidi için suluda yaprak solüsyon denemesindeki tane protein ile kalite parametreleri arasındaki korelasyon katsayıları da Çizelge 7'de verilmiştir.

$\mathrm{Bu}$ özeliklerden, protein fraksiyonlarından glutenin grubuyla daha yakın ilişkili olduğu ifade edilenler yanında, uzama kabiliyeti ve uzayabilirlik gibi gliadin gurubuyla ilişkili olduğu belirtilenler de vardır (Foulkes ve ark., 2009). Azotlu gübrelemenin toplam proteinde sağladığı artış genelde depo proteinleri olarak adlandırılan glutenin ve gliadin gurubu proteinleri arttırarak olduğu için (Stein ve ark., 1992; Johansson ve ark., 2001) proteinle birlikte bu kalite özelliklerinin de gelișmesi mümkün olmakta, ancak tane doldurma sürecindeki diğer çevre koşulları protein guruplarının oransal durumunu etkilemektedir (Jamieson ve ark., 2001).

\section{Sonuçar}

Başaklanma zamanında yapılan azot uygulamalarının tane protein kapsamı ve onunla ilgili ekmeklik kalite değerleri üzerine olumlu katkısı sulu koşullarda net olarak ortaya çıkmıştır. $\mathrm{Bu}$ yaklaşımın pratiğe aktarılmasında gerekli olacak gerek klorofilmetre okumalarına gerekse yaprak toplam azot kapsamlarına ait kritik eşik değerleri elde edilmiştir. $\mathrm{Bu}$ araştırmada, sulu koşullarda, başaklanma döneminde yapraktan üre uygulaması Bezostayal'in tane protein kapsamını \%2,6'llk artışla $\% 12,9$ 'dan \%15,5'e, yükselmiștir. Sulu koşullarda kritik eşik olarak belirlenen 0,95 NSPAD ve bayrak yaprak toplam azot kapsamı içinse \%4,31 TN değerlerinin üzerinde okuma yapıldığında geç dönem azot uygulaması $\% 1$ ve üzerinde protein artışı sağlamadığı için ekonomik olmamakta, bu kritik eşik değerlerinin altındaki okumalarda ise NSPAD değeri düştükçe ekonomik azot dozu artmaktadır. Sonuç olarak; sulu koşullarda kritik eşik olarak belirlenen NSPAD değerlerinin üzerinde okuma yapıldığında geç dönem azot uygulaması $\% 1$ ve üzerinde protein artışı sağlamadığı için ekonomik olmamakta, bu kritik eşik değerlerinin altındaki okumalarda ise NSPAD değeri düştükçe ekonomik azot dozu artmaktadır. Bu hususun dikkate alınması erken dönemde fazla azot kullanılan ve/veya pancar, patates gibi toprakta fazla bakiye azot birakan münavebe bitkilerinden sonra ekilen buğdayda, bu dönemde gereksiz azot kullanımını engelleyerek, girdi ekonomisine yararlı olacaktır.

\section{Teșekkür}

$\mathrm{Bu}$ bildiri, TÜBITTAK-KAMAG tarafindan desteklenen 106G111 nolu proje kapsamında yapılan araştırma sonuçlarından hazırlanmıştır. Söz konusu projenin Ülkemiz için gerekliliğine inanarak müşteri olan Gıda, Tarım ve Hayvancılık Bakanlı̆̆ ve Tarımsal Araştırmalar ve Politikalar Genel Müdürlüğüne ve destekleyen TÜBITTAK'a bütün proje ekibi olarak teşekkür ederiz.

\section{Kaynaklar}

AACC. 2000. Approved Methods of the Amaerican Association of Cereal Chemists. $10^{\text {th }}$ edn. St.Paul, MN: USA. American Association of Cereal Chemists.

Anonymous. 2000. AACC Method 54-21, AACC Method 5410, Modifiye AACC Method 54-30 ve AACC Method 5450, AACC Method 56-11, Approved Methods of American Association of Cereal Chemists.

Atlı A. 1987. Kışlık tahıl üretim bölgelerimizde yetiştirilen bazı ekmeklik ve makarnalık buğday çeşitlerinin kaliteleri ile kalite karakterlerinin stabilitesi üzerine araştırmalar. Türkiye Tahıl Sempozyumu, 443-455, Bursa. 
Austin RB, Ford MA, Edrich JA, Blackwell RD. 1977. The nitrogen economy of winter wheat. Journal of Agricultural Science, Cambridge 88, 159-167.

Bremner JM, 1965. Nitrogen Ed.: C.A.Black. In: Method of Soil Analysis. Part:II. Chemical and Microbiological Properties. Agronomy Series. No:9. Agron. Inc. Madison. Wisconsin. USA.

Bushuk W. 1998. Wheat breeding for end-product use. Euphytica, 100, 137-145.

Carson GR, Edwards NM. 2009. Criteria of wheat and flour quality. In: Khan K. ve P.R. Shewry. (eds.). Wheat chemistry and technology 4th ed., AACC International Inc., MN, USA, pp. 97-118

Doerge TA, Roth RL, Gardner BR.1991. Nitrogen Fertilizer Management in Arizona. Univ. of Arizona, Tucson, AZ

Finney KF, Meyer JW, Smith FW, Fryer HC. 1957. Effect of foliar spraying of Pawnee wheat with urea solutions on yield, protein content, and protein quality. Agron. J. 49:341347.

Foulkes MJ, Hawkesford MJ, Barraclough PB, Holdsworth MJ, Kerr S, Kightley S, Shewry PR. 2009. Identifying traits to improve the nitrogen economy of wheat: Recent advances and future prospects. Field Crops Res. 114: 329-342.

Frederick JR, Bauer PJ. 1999. Physiological and numerical components of wheat yield. P 56. In E.H. Satorre and G.A. Slafer (ed) Wheat: Ecology and physiology of yield determination. Food Products Press, New York.

Heitholt JJ, Croy LI, Maness NO, Ngyuen HT. 1990. Nitrogen partitioning in genotypes of winter wheat differing in grain N concentration. Field Crops Research 23, 133-144.

JMP. 2016. JMP Users Guide. Version 13.0.0, SAS Institute Inc., Cary, NC, USA.

Jamieson PD, Stone PJ, Semenov MA. 2001. Towards modelling quality in wheat from grain nitrogen concentration to protein composition. Aspects of Applied Biology 64, 111-126.

Johansson E, Prieto-Linde ML, Jonsson JO. 2001. Effects of wheat cultivar and nitrogen application on storage protein composition and breadmaking quality. Cereal Chemistry 78, $19-25$.

Karaduman Y, Akın A, Türkölmez S, Tunca ZŞ, Belen S, Çakmak M, Yüksel S. 2015. İleri Kademe Ekmeklik Buğday Hatlarının Bazı Teknolojik Kalite Özelliklerinin Değerlendirilmesi.Tarla Bitkileri Merkez Araştırma Ens. Der. cilt:24, say1:1, s: 24-29.

Lorbeer S, Acobsen J, Bruckner P, Wichman D, Berg J. 2000. Capturing the genetic protein potential in winter wheat. Fertilizer Facts. Number 23. Montana State Univ.

Markwell J, Osterman JC, Mitchell JL. 1995. Calibration of the Minolta SPAD-502 leaf chlorophyll mater. Photosyn. Res. 46, 467-472.
Oscarson P, Lundborg T, Larsson M, Larsson CM. 1995. Genotypic differences in nitrate uptake and nitrogen utilization for spring wheat grown hydroponically. Crop Science 35: 1056-1062.

Peoples MB, Dalling MJ. 1988. The interplay between proteolysis and amino acid metabolism during senescence and nitrogen reallocation. p. 181-217. In L.D. Noodén and A.C. Leopold (ed). Senescence and Aging in Plants. Academic Press, San Diego

Pena RJ, Amaya A, Rajaram S, Mujeeb-Kazi A. 1990. Variation in quality characteristics with some spring $1 \mathrm{~B} / 1 \mathrm{R}$ translocation wheats. Journal of Cereal Sci., 12: 105-112.

Peng S, Garcia FV, Laza RC, Sanico AL, Visperas RM, Cassman KG. 1996. Increased N-use efficiency using a chlorophyll meter on high-yielding irrigated rice. Field Crop. Res. 47: 243-252.

Savasli E, Önder O, Cekic C, Kalaycı HM, Dayığlu R, Karaduman Y, Gökmen F, Dursun N, Gezgin S.2017. The Effects of Foliar Nitrogen Treatments at Heading Stage on Grain Protein Contents of Bread Wheat Cultivars selcukj.agr.Food SCi. 31(1): 42-47

Stein IS, Sears RG, Hoseney RC, Cox TS, Gill BS. 1992. Chromosomal location of genes influencing grain protein concentration and mixogram properties in Plainsman-V winter wheat. Crop Sci: 573-80.

Strong WM. 1982. Effect of late application of $\mathrm{N}$ on the yield and protein content of wheat. Aust. J. Exp. Agric. Anim. Husb. 22: 54-61.

Topal A, Sade B, Soylu S, Öztürk Ö, Kan Y, Kenbaev B. 1997. Farklı gelişme dönemlerinde değişik azotlu gübre formlarının yapraktan ve topraktan uygulamasının ekmeklik ve makarnalık buğday çeşitlerinin tane verimi, bazı verim ve kalite unsurlarına etkileri.Türkiye II. Tar. Bit. Kon. 22-25 Eyl.1997, s: 51-55, Samsun.

Westcott M, Eckhoff J, Engel R, Jacobsen J, Jackson G, Stongaard B.1997. Flag leaf diagnosis of grain protein response to late-season $\mathrm{N}$ application in irrigated spring wheat. Fertilizer Facts. Number 12. Montana State University.

Wuest SB, Cassman KG. 1992. Fertilizer-nitrogen use efficiency of irrigated wheat: I. Uptake efficiency of preplant versus late-season application. Ag.J.84: 682-688.

Van Sanford DA, Mac Kown CT. 1987. Cultivar differences in nitrogen remobilization during grain fill in soft red winter wheat. Crop Science 27: 295-300.

Zeleny L. 1971. Criteria of wheat quality, in Wheat Chemistry and Technology. Ed by Y.Pomeranz, AACC St Paul, MN, USA.

Zhu J, Khan K. 2001. Effects of genotype and environment on glutenin polymers and bread making quality. Cereal Chemistry 78: $125-130$. 